\title{
Numerical and experimental investigation of the thermal and electrical characteristics of a lithium ion cell
}

\author{
Tanılay Özdemir ${ }^{1 *}$, Özgür Ekici ${ }^{1}$, and Murat Köksal ${ }^{1}$ \\ ${ }^{1}$ Department of Mechanical Engineering, Hacettepe University, 06800, Beytepe, Ankara, Turkey
}

\begin{abstract}
In this study, an electrochemical-thermal coupled model was developed to investigate the electrical and thermal behaviors of the commercial NCR18650b Li-ion cell during three different discharge rates. The 1-dimensional electrochemical model consists of a positive electrode, electrolyte, and a negative electrode and employs the related mass and charge transfer equations for both solid and liquid phases predicting the cell's voltage variation. The 3-dimensional thermal model involves a mandrel, an active battery part, and a shell. The thermal model solves the general heat diffusion equation and predicts the temperature variation of the cell. The results show that the predicted temperature-voltage profiles follow the same trend with experimental data and are consistent. The maximum calculated root mean square errors are obtained as $0.11 \mathrm{~V}$ for voltage, and $0.96{ }^{\circ} \mathrm{C}$ for temperature predictions. On the other hand, the maximum temperature differences within the cell was found to be $0.16{ }^{\circ} \mathrm{C}, 0.43{ }^{\circ} \mathrm{C}$, and $1.29{ }^{\circ} \mathrm{C}$ after the $0.5 \mathrm{C}, 1 \mathrm{C}$ and $1.5 \mathrm{C}$ rate discharging processes, respectively. Finally, the results from the 3 -dimensional thermal model reveal that the type of mandrel affects the temperature variation within the cell. However, the average surface temperature of the cell remains comparable for the investigated $\mathrm{C}$ rates.
\end{abstract}

\section{Nomenclature}

Symbol
$\mathrm{A}$
$\mathrm{a}_{\mathrm{s}}$
$\mathrm{c}_{\mathrm{l}}$
$\mathrm{c}_{\mathrm{p}}$
$\mathrm{c}_{\mathrm{s}}$
$\mathrm{D}_{\mathrm{l}}$
$\mathrm{D}_{\mathrm{s}}$
$\mathrm{E}_{\mathrm{eq}}$
$\mathrm{F}$
$\mathrm{H}$
$\mathrm{h}$
$\mathrm{I}$
$\mathrm{I}_{\mathrm{a}_{\mathrm{p}}}$
$\mathrm{i}_{\mathrm{o}}$
$\mathrm{J}_{\mathrm{Li}}$
$\mathrm{k}_{\mathrm{c}}$
$\mathrm{k}_{\mathrm{a}}$
$\mathrm{k}_{\mathrm{b}}$
$\mathrm{L}$
$\mathrm{r}$
$\mathrm{P}$
$\mathrm{Q}_{\mathrm{Q}}$
$\mathrm{R}$
$\mathrm{R}_{\mathrm{s}}$
$\mathrm{T}$
$\mathrm{t}_{+}$

\section{Parameter}

Electrode plate area, $\mathrm{m}^{2}$

Electrode specific surface area, $\mathrm{m}^{2} / \mathrm{m}^{3}$

Lithium ion concentration in the

liquid phase, $\mathrm{mol} / \mathrm{m}^{3}$

Specific heat of the cell, $\mathrm{kj} / \mathrm{kgK}$

Lithium ion concentration in the solid phase, $\mathrm{mol} / \mathrm{m}^{3}$

Electrolyte diffusion coefficient, $\mathrm{m}^{2} / \mathrm{s}$

Solid phase diffusion coefficient, $\mathrm{m}^{2} / \mathrm{s}$

Equilibrium potential, $\mathrm{V}$

Faraday's constant, C/mol Height, $\mathrm{mm}$

Convective heat transfer coefficient, $\mathrm{W} / \mathrm{m}^{2} \mathrm{~K}$

Applied current, A

Applied current density, $\mathrm{A} / \mathrm{m}^{2}$

Exchange current density, $\mathrm{A} / \mathrm{m}^{2}$

Volumetric rate of electrochemical reaction at the particle surface, $\mathrm{A} / \mathrm{m}^{3}$

Cathodic rate constant, $\mathrm{m}^{2.5} /\left(\mathrm{mol}^{0.5} \mathrm{~s}\right)$

Anodic rate constant, $\mathrm{m}^{2.5} /\left(\mathrm{mol}^{0.5} \mathrm{~s}\right)$

Stefan-Boltzmann constant, $\mathrm{W} / \mathrm{m}^{2} \mathrm{~K}^{4}$ Length, mm

Radial direction, $\mu \mathrm{m}$

Bruggeman coefficient

Volumetric heat generation, $\mathrm{W} / \mathrm{m}^{3}$

Universal gas constant, $\mathrm{J} / \mathrm{molK}$

Average radius of the active spherical particle, $\mu \mathrm{m}$

Absolute temperature, $\mathrm{K}$

Transference number lithium ions

Greek Symbol
$\alpha_{\mathrm{a}}$
$\alpha_{\mathrm{c}}$
$\varepsilon$
$\varepsilon_{\mathrm{l}}$
$\varepsilon_{\mathrm{s}}$
$\sigma_{\mathrm{s}}$
$\sigma_{\mathrm{l}}$
$\phi_{\mathrm{l}}$
$\phi_{\mathrm{s}}$
$\rho$
$\eta$
$\lambda$
Indices
ang
bat
eq
IR
init
$\mathrm{J}$
1
max
ne
necc
pe
pecc
rd
REV
$\mathrm{s}$
sep

Parameter
Anodic charge transfer coefficient
Cathodic charge transfer coefficient
Emissivity
Electrolyte volume fraction
Solid phase volume fraction
Electrical conductivity, S/m
Electrolyte conductivity, $\mathrm{S} / \mathrm{m}$
Electrolyte phase potential, V
Solid phase potential, V
Density, kg/m ${ }^{3}$
Overpotential, V
Whermal conductivity of the cell,
W/mK
Parameter
Angular
Battery
Equilibrium
Irreversible
İnitial
Joule
Liquid
Maximum
Negative electrode
Positive electrode
Soparator
Reversible
Solid

* Corresponding author: tanilayozdemir@hacettepe.edu.tr 


\section{Introduction}

As a reliable energy storage system, Li-ion batteries are one of the favored options due their relatively higher energy density and longer cycling life compared to other types of batteries. The Li-ion batteries can be used in both low and high-power-needed applications as they can be connected in series or parallel to sustain the required voltage and capacity whenever it is demanded. Despite their prominent above-stated advantages, the thermal behavior of Li-ion batteries is one of the critical areas and reliable models are still under development for prediction of electrical and thermal performances under normal and abuse operating conditions. The electrochemical-thermal coupled modeling is one of the viable options that can potentially predict the electrical and thermal characteristics of the battery accurately. In the literature, there are significant numbers of studies that employ the electrochemical-thermal coupled model for various types of cells including prismatic [1-8], pouch $[9,10]$, and cylindrical cells with $14 \mathrm{~mm}[11], 18$ $\mathrm{mm}[11,12], 26 \mathrm{~mm}[11,13,14]$ and $38 \mathrm{~mm}$ [15] diameters. The thermal model employs the solution of the general heat diffusion equation considering the convective and radiative heat transfers on the cell surface. The radiative heat transfer may be assumed ineffective for the cases that cannot reach elevated cell temperatures. However, the convective heat transfer considerably affects the heat dissipation from the cell. In the literature, the convective heat transfer coefficient is mostly assumed constant as presented in the table below. However, it is known that the temperature field around the cell has an impact on the convective heat transfer coefficient during a discharging process. To the author's knowledge, the presented studies that apply electrochemical-thermal coupled models have not considered the effects of the varying convective heat transfer coefficient.

Table 1. Convective heat transfer coefficient values used in electrochemical-thermal coupled models in the literature

\begin{tabular}{|c|c|}
\hline $\mathbf{h}\left(\mathbf{W m}^{-\mathbf{2}} \mathbf{K}^{-\mathbf{1}}\right)$ & References \\
\hline $0-\mathbf{5}$ & {$[10],[13],[15-17]$} \\
\hline $5-10$ & {$[3-5],[12-14],[17]$} \\
\hline $10-\mathbf{5 0}$ & {$[4-6],[11],[13]$} \\
\hline $50-\mathbf{1 5 0}$ & {$[5],[6],[16]$} \\
\hline $150-350$ & {$[4]$} \\
\hline
\end{tabular}

*Bold numbers are included in the given range.

In this study, an electrochemical-thermal coupled model was developed for a NCR18650 Li-ion cell and model results were verified with experimental measurements. The model input parameters were obtained by a comprehensive literature survey. The total heat generation within the cell was evaluated by considering the Joule heating, overpotential heating, and entropic heating terms. The evaluated heat generation was employed in the heat diffusion equation to define the temperature variation of the cell. The convective and radiative heat transfers were defined as a boundary condition to the surface of the cell. The variable convective heat transfer coefficient was determined using the well-known Churchill-Chu correlation.

In the experimental part, standard $0.5,1$, and 1.5 C-rate discharging tests were performed and the voltage and temperature variations of the cell were obtained. The predicted voltage and temperature profiles were then compared with the experimental results and reasonable agreement was achieved. Consequently, the results from the 3-D thermal model reveal that the type of mandrel affects the temperature variation within the cell. However, the predicted average surface temperature of the cell remains comparable, within the $\mathrm{C}$ rates investigated.

\section{Methodology}

A typical Li-ion cell consists of an anode (negative electrode), a cathode (positive electrode), a separator to divide the positive and negative electrodes from each other as an electrical insulator, the electrolyte to provide movement of lithium ions between electrodes during charging and discharging, current collectors, and a case to cover these components [18]. Fig. 1 shows a schematic representation of a Li-ion battery.

Lithium ions are removed from the positive electrode and travel through the separator to the negative electrode during the charging process. The same number of electrons are released concurrently from the cathode side to provide the electrical balance. The positive current collector receives the electrons. These electrons flow to the negative electrode through the external circuit to create the charge current. The inverse process occurs during the discharging process [19].

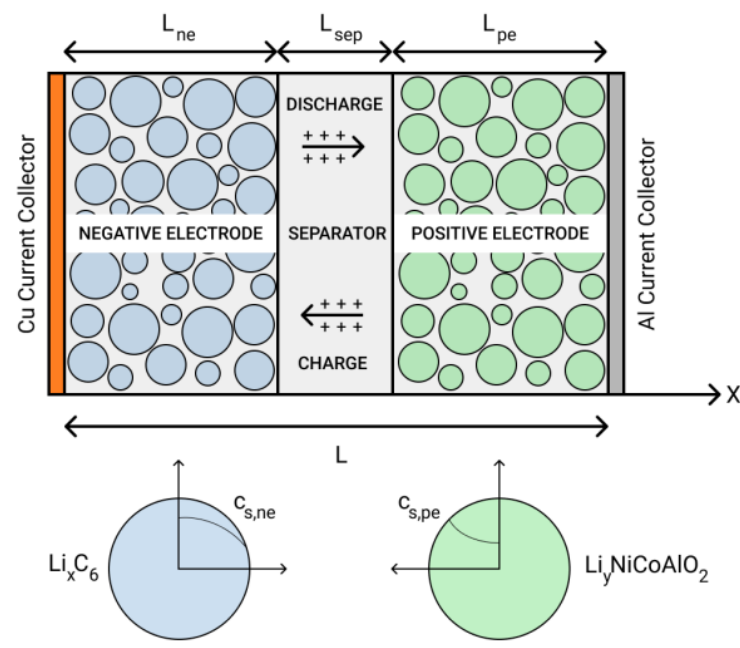

Fig. 1. A schematically representation of a Li-ion cell.

\subsection{Electrochemical model}

The electrochemical process inside the battery takes place in two different phases, the solution phase (electrolyte) and the solid phase (electrodes). In this part, the mass and charge balances for liquid and solid phases are investigated in one dimension considering the porous electrode theory by Newman et al. [20, 21]. 


\subsubsection{Li-ion concentration in the solid phase}

Fick's law of diffusion defines the conservation of lithium ions in a solid spherical particle as,

$$
\frac{\partial c_{s}}{\partial t}=\frac{D_{s}}{r^{2}} \frac{\partial}{\partial r}\left(\mathrm{r}^{2} \frac{\partial \mathrm{c}_{\mathrm{s}}}{\partial \mathrm{r}}\right)
$$

where $\mathrm{c}_{\mathrm{s}}$ is the lithium ion concentration in the solid phase, $D_{s}$ is the solid phase diffusion coefficient, $t$ is the time, and $\mathrm{r}$ represents the radial direction in the solid spherical particle. No flux at the center of the spherical particle is assumed.

$$
\left.\frac{\partial \mathrm{c}_{\mathrm{s}}}{\partial \mathrm{r}}\right|_{\mathrm{r}=0}=0
$$

In the meantime, the molar flux of lithium at the solid-liquid interface can be described by Eqn. (3)

$$
-\left.\mathrm{D}_{\mathrm{s}} \frac{\partial \mathrm{c}_{\mathrm{s}}}{\partial \mathrm{r}}\right|_{\mathrm{r}=\mathrm{R}_{\mathrm{s}}}=\frac{\mathrm{J}_{\mathrm{Li}}}{\mathrm{a}_{\mathrm{s}} \mathrm{F}}
$$

where $R_{s}$ is the radius of the spherical particle, $J_{\mathrm{Li}}$ denotes the volumetric rate of electrochemical reaction at the particle surface, $\mathrm{F}$ is the Faraday's constant, and $\mathrm{a}_{\mathrm{s}}$ is the electrode specific surface area.

\subsubsection{Li-ion concentration in the liquid phase}

The mass balance for the lithium ions in the liquid phase can be described by Eqn. (4)

$$
\frac{\partial\left(\varepsilon_{1} c_{l}\right)}{\partial t}=\frac{\partial}{\partial x}\left(D_{l, e f f} \frac{\partial c_{l}}{\partial x}\right)+\left(1-t_{+}\right) \frac{J_{L i}}{F}
$$

where $\varepsilon_{1}$ denotes the electrolyte volume fraction, $\mathrm{c}_{1}$ is the lithium ion concentration in the liquid phase, $\mathrm{D}_{\mathrm{l} \text { eff }}$ is the effective electrolyte diffusion coefficient and $t_{+}$is the transference number of lithium ions. Eqns. (5) and (6) indicate that no fluxes can be observed at the $\mathrm{x}=0$, and $\mathrm{x}=\mathrm{L}$ since the current collectors don't pass the lithium ions. However, the flux is continuous at each interface as can be seen from Eqns. (7) and (8).

$$
\begin{gathered}
-\left.D_{\mathrm{l}, \mathrm{eff}} \mathrm{ne} \frac{\partial \mathrm{c}}{\partial \mathrm{x}}\right|_{\mathrm{x}=0}=0 \\
-\left.\mathrm{D}_{\mathrm{l}, \mathrm{eff}} \mathrm{pe} \frac{\partial \mathrm{c}}{\partial \mathrm{x}}\right|_{\mathrm{x}=\mathrm{L}}=0 \\
-\left.\mathrm{D}_{\mathrm{l}, \mathrm{eff}} \mathrm{ne} \frac{\partial \mathrm{c}}{\partial \mathrm{x}}\right|_{\mathrm{x}=\mathrm{L}_{\mathrm{ne}}^{-}}=-\left.\mathrm{D}_{\mathrm{l}, \mathrm{eff}} \operatorname{sep} \frac{\partial \mathrm{c}}{\partial \mathrm{x}}\right|_{\mathrm{x}=\mathrm{L}_{\mathrm{ne}}^{+}} \\
-\mathrm{D}_{\mathrm{l}, \mathrm{eff}} \text { sep }\left.\frac{\partial \mathrm{c}}{\partial \mathrm{x}}\right|_{\mathrm{x}=\left(\mathrm{L}_{\mathrm{ne}}+\mathrm{L}_{\mathrm{sep}}\right)^{-}} \\
=-\left.\mathrm{D}_{\mathrm{l}, \mathrm{eff}} \mathrm{pe} \frac{\partial \mathrm{c}}{\partial \mathrm{x}}\right|_{\mathrm{x}=\left(\mathrm{L}_{\mathrm{ne}}+\mathrm{L}_{\mathrm{sep}}\right)^{+}}
\end{gathered}
$$

On the other hand, the separator allows the lithium ions to move continuously at the interfaces between the electrodes in Eqn. (9) and the separator in Eqn. (10).

$$
\begin{gathered}
\left.\mathrm{c}_{l}\right|_{\mathrm{x}=\mathrm{L}_{\mathrm{ne}}^{-}}=\mathrm{c}_{l_{\mathrm{x}=\mathrm{L}_{\mathrm{ne}}^{+}}} \\
\left.\mathrm{c}_{l}\right|_{\mathrm{x}=\left(\mathrm{L}_{\mathrm{ne}}+\mathrm{L}_{\mathrm{sep}}\right)^{-}}=\left.\mathrm{c}_{l}\right|_{\mathrm{x}=\left(\mathrm{L}_{\mathrm{ne}}+\mathrm{L}_{\mathrm{sep}}\right)^{+}}
\end{gathered}
$$

\subsubsection{Charge conservation in the solid phase}

Ohm's law defines the charge conservation in the solid phase,

$$
\frac{\partial}{\partial \mathrm{x}}\left(\sigma_{\mathrm{s}, \mathrm{eff}} \frac{\partial \phi_{\mathrm{s}}}{\partial \mathrm{x}}\right)=\mathrm{J}_{\mathrm{Li}}
$$

where $\phi_{\mathrm{s}}$ is the solid phase potential, $\sigma_{\mathrm{s}, \mathrm{eff}}$ denotes the effective electrical conductivity, and can be evaluated by the following equation.

$$
\sigma_{\mathrm{s}, \mathrm{eff}}=\sigma_{\mathrm{s}} \cdot \varepsilon_{\mathrm{s}}^{\mathrm{p}}
$$

In Eqn. (12), $\sigma_{\mathrm{s}}$ is the electrical conductivity, $\varepsilon_{\mathrm{s}}$ is the solid phase volume fraction, and $\mathrm{p}$ denotes the Bruggeman coefficient. Eqn. (13) denotes the charge flux is equal to the current density at the end of the cell,

$$
-\left.\sigma_{\mathrm{s}, \mathrm{eff}} \mathrm{pe} \frac{\partial \phi_{\mathrm{s}}}{\partial \mathrm{x}}\right|_{\mathrm{x}=\mathrm{L}}=\mathrm{I}_{\mathrm{app}}=\frac{\mathrm{I}}{\mathrm{A}}
$$

where $I_{a p p}$ is the applied current density, $I$ is the applied current and $\mathrm{A}$ is the electrode plate area. Charge flux is not allowed at each interface so that the Eqns. (14) and (15) should be equal to zero.

$$
\begin{gathered}
-\left.\sigma_{\mathrm{s}, \mathrm{eff}} \mathrm{ne} \frac{\partial \phi_{\mathrm{s}}}{\partial \mathrm{x}}\right|_{\mathrm{x}=\mathrm{L}_{\mathrm{ne}}}=0 \\
-\left.\sigma_{\mathrm{s}, \mathrm{eff}} \mathrm{pe} \frac{\partial \phi_{\mathrm{s}}}{\partial \mathrm{x}}\right|_{\mathrm{x}=\mathrm{L}_{\mathrm{ne}}+\mathrm{L}_{\mathrm{sep}}}=0
\end{gathered}
$$

\subsubsection{Charge conservation in the liquid phase}

The charge conservation in the liquid phase is defined by Eqn. (16),

$$
\begin{gathered}
\frac{\partial}{\partial \mathrm{x}}\left(-\sigma_{\mathrm{l}, \mathrm{eff}} \frac{\partial \phi_{\mathrm{l}}}{\partial \mathrm{x}}+2 \mathrm{RT} \sigma_{\mathrm{l}, \mathrm{eff}} \frac{\left(1-\mathrm{t}_{+}\right)}{\mathrm{F}} \frac{\partial \ln \mathrm{c}_{\mathrm{l}}}{\partial \mathrm{x}}(1\right. \\
\left.\left.+\frac{\partial \operatorname{lnf}}{\partial \ln \mathrm{c}_{\mathrm{l}}}\right)\right)=\mathrm{J}_{\mathrm{Li}}
\end{gathered}
$$

where $\phi_{1}$ is the electrolyte phase potential, $\mathrm{f}$ is the electrolyte activity coefficient, $\mathrm{R}$ is the universal gas constant, $\mathrm{T}$ denotes the temperature, and $\sigma_{\mathrm{l} \text { eff }}$ is the effective electrolyte conductivity which can be expressed by Eqn. (17),

$$
\sigma_{\mathrm{l}, \mathrm{eff}}=\sigma_{\mathrm{l}} \cdot \varepsilon_{\mathrm{l}}^{\mathrm{p}}
$$

where $\sigma_{1}$ shows the electrolyte conductivity. Eqns. (18) and (19) show that no charge flux is allowed at $x=0$, and $\mathrm{x}=\mathrm{L}$ in the electrolyte phase, respectively.

$$
\begin{aligned}
& -\left.\sigma_{\mathrm{l}, \mathrm{eff}} \mathrm{ne} \frac{\partial \phi_{\mathrm{l}}}{\partial \mathrm{x}}\right|_{\mathrm{x}=0}=0 \\
& -\left.\sigma_{\mathrm{l}, \mathrm{eff}} \mathrm{pe} \frac{\partial \phi_{\mathrm{l}}}{\partial \mathrm{x}}\right|_{\mathrm{x}=\mathrm{L}}=0
\end{aligned}
$$

On the other hand, Eqns. (20-23) indicate that the potentials and their fluxes are continuous at the interfaces. 


$$
\begin{aligned}
&\left.\phi_{\mathrm{l}}\right|_{\mathrm{x}=\mathrm{L}_{\text {ne }}^{-}}=\left.\phi_{\mathrm{l}}\right|_{\mathrm{x}=\mathrm{L}_{\text {ne }}^{+}} \\
&\left.\phi_{\mathrm{l}}\right|_{\mathrm{x}=\left(\mathrm{L}_{\mathrm{ne}}+\mathrm{L}_{\mathrm{sep}}\right)^{-}}=\left.\phi_{\mathrm{l}}\right|_{\mathrm{x}=\left(\mathrm{L}_{\mathrm{ne}}+\mathrm{L}_{\mathrm{sep}}\right)^{+}} \\
&-\left.\sigma_{\mathrm{l}, \mathrm{eff}} \mathrm{ne} \frac{\partial \phi_{\mathrm{l}}}{\partial \mathrm{x}}\right|_{\mathrm{x}=\mathrm{L}_{\text {ne }}^{-}}=-\left.\sigma_{\mathrm{l}, \mathrm{eff}} \operatorname{sep} \frac{\partial \phi_{\mathrm{l}}}{\partial \mathrm{x}}\right|_{\mathrm{x}=\mathrm{L}_{\mathrm{ne}}^{+}} \\
&-\left.\sigma_{\mathrm{l}, \mathrm{eff}} \operatorname{sep} \frac{\partial \phi_{\mathrm{l}}}{\partial \mathrm{x}}\right|_{\mathrm{x}=\left(\mathrm{L}_{\mathrm{ne}}+\mathrm{L}_{\mathrm{sep}}\right)^{-}}= \\
&-\left.\sigma_{\mathrm{l}, \mathrm{eff}} \mathrm{pe} \frac{\partial \phi_{\mathrm{l}}}{\partial \mathrm{x}}\right|_{\mathrm{x}=\left(\mathrm{L}_{\mathrm{ne}}+\mathrm{L}_{\mathrm{sep}}\right)^{+}}
\end{aligned}
$$

\subsubsection{Electrode kinetics}

The charge transfer reactions can be expressed by Butler- Volmer equation,

$$
J_{L i}=\mathrm{i}_{0} a_{s}\left[\exp \left(\frac{\alpha_{\mathrm{a}} \mathrm{F}}{\mathrm{RT}} \eta\right)-\exp \left(-\frac{\alpha_{\mathrm{c}} \mathrm{F}}{\mathrm{RT}} \eta\right)\right]
$$

where, $\alpha_{\mathrm{a}}$ is the anodic; $\alpha_{\mathrm{c}}$ is the cathodic charge transfer coefficient, $\eta$ denotes the overpotential, and $i_{0}$ represents the exchange current density as,

$$
\mathrm{i}_{0}=F\left(\mathrm{k}_{\mathrm{c}}\right)^{\alpha_{\mathrm{a}}}\left(\mathrm{k}_{\mathrm{a}}\right)^{\alpha_{\mathrm{c}}}\left(\mathrm{c}_{\mathrm{s}}\right)^{\alpha_{\mathrm{c}}}\left(\mathrm{c}_{\mathrm{l}}\right)^{\alpha_{\mathrm{a}}}\left(\mathrm{c}_{\mathrm{s}, \text { max }}-\mathrm{c}_{\mathrm{s}}\right)^{\alpha_{\mathrm{a}}}
$$

In this equation, $\mathrm{k}_{\mathrm{a}}$ denotes the anodic rate constant whereas $k_{c}$ indicates the cathodic rate constant. The overpotential term can be evaluated from Eqn. (26)

$$
\eta=\phi_{\mathrm{s}}-\phi_{\mathrm{l}}-\mathrm{E}_{\mathrm{eq}}
$$

where $E_{e q}$ defines the equilibrium potential.

\subsection{Thermal model}

The general heat diffusion equation for the energy conservation is stated as:

$$
\rho c_{p}\left(\frac{\partial T}{\partial \mathrm{t}}\right)=\nabla \cdot \lambda \nabla \mathrm{T}+\dot{\mathrm{Q}}_{\text {total }}
$$

where, $T$ is the temperature, $\rho$ is the density, $c_{p}$ is the specific heat of the cell, $\lambda$ is the thermal conductivity of the cell, and $\dot{Q}_{\text {total }}$ is the total volumetric heat generation within the cell. The corresponding boundary condition at the surface of the cell can be indicated as,

$$
(\lambda \nabla \mathrm{T})=-\mathrm{h}\left(\mathrm{T}_{\mathrm{s}}-\mathrm{T}_{\text {surr }}\right)-\varepsilon \mathrm{k}_{\mathrm{b}}\left(\mathrm{T}_{\mathrm{s}}^{4}-\mathrm{T}_{\text {surr }}^{4}\right)
$$

where $T_{s}$ denotes the surface temperature of the cell, $\mathrm{T}_{\text {surr }}$ states the temperature of the surrounding area, $\mathrm{h}$ is the convective heat transfer coefficient, $\varepsilon$ is the emissivity, and $\mathrm{k}_{\mathrm{b}}$ is the Stefan-Boltzmann constant. Churchill-Chu correlation is used to determine the convective heat transfer coefficient that varies during the discharging processes.

The total heat generation is evaluated by considering the Joule heating, overpotential heating and the entropic heating within the cell. In the model, the Joule heating due to the charge transfer relations is defined in Eqn. (29).

$$
\begin{gathered}
\dot{\mathrm{Q}}_{\mathrm{J}}=\left(\sigma_{\mathrm{s}, \mathrm{eff}} \frac{\partial^{2} \phi_{\mathrm{s}}}{\partial \mathrm{x}^{2}}\right)+\left(\sigma_{\mathrm{l}, \mathrm{eff}} \frac{\partial \phi_{\mathrm{l}}}{\partial \mathrm{x}}+\right. \\
\left.2 \mathrm{RT} \sigma_{\mathrm{l}, \mathrm{eff}} \frac{\left(1-\mathrm{t}_{+}\right)}{\mathrm{F}} \frac{\partial \ln \mathrm{c}_{\mathrm{l}}}{\partial \mathrm{x}}\left(1+\frac{\partial \operatorname{lnf}}{\partial \ln \mathrm{c}_{\mathrm{l}}}\right)\right) \frac{\partial \phi_{\mathrm{l}}}{\partial \mathrm{x}}
\end{gathered}
$$

The irreversible heat generation is related with the overpotential term and can be determined with the following equation [22],

$$
\dot{\mathrm{Q}}_{\mathrm{IR}}=\mathrm{J}_{\mathrm{Li}} \eta
$$

whereas the reversible heat generation is the function of temperature derivative of the equilibrium potential and expressed in Eqn. (31) [22],

$$
\dot{\mathrm{Q}}_{\mathrm{REV}}=\mathrm{J}_{\mathrm{Li}} \mathrm{T} \frac{\partial \mathrm{E}_{\mathrm{eq}}}{\partial \mathrm{T}}
$$

Therefore, the total volumetric heat generation within the cell can be evaluated as in Eqn. (32)

$$
\dot{\mathrm{Q}}_{\text {total }}=\dot{\mathrm{Q}}_{\mathrm{REV}}+\dot{\mathrm{Q}}_{\mathrm{IR}}+\dot{\mathrm{Q}}_{\mathrm{J}}
$$

\subsection{Experimental procedure}

Fig. 2 shows the experimental set up which involves the Maccor 4300 Test Equipment, NCR18650 Li-ion batteries, T-type thermocouples, Plexiglass stand, and National Instrument Data Acquisition device.

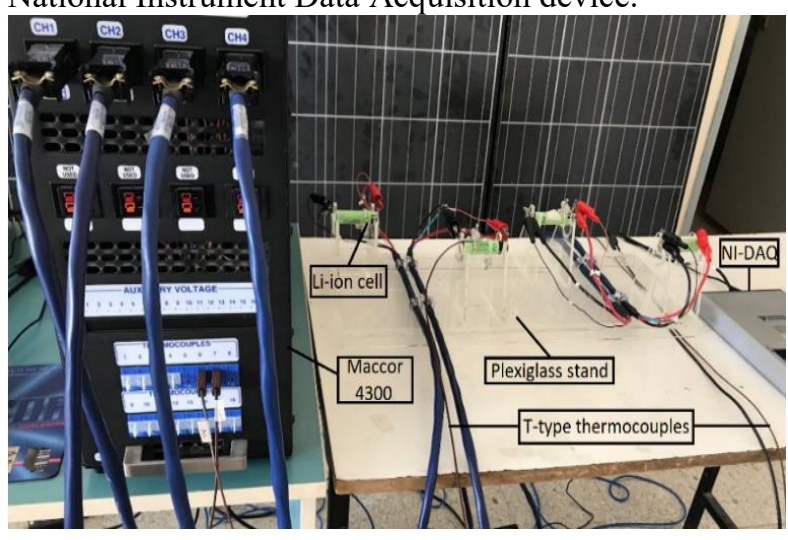

Fig. 2. Battery testing system.

In the experimental part of this study, galvanostatic discharging tests were conducted at $0.5,1$, and $1.5 \mathrm{C}$ rates to obtain the voltage and the temperature variations of the cylindrical NCR18650b cell. Maccor test equipment was used to apply the discharge loads and monitor the instantaneous voltage values of the cell with maximum $\pm 0.84 \mathrm{mV}$ accuracy. The voltage of the cell was limited to $2.5 \mathrm{~V}$ for all discharging processes due to safety factors. On the other hand, surface temperature measurements were carried out through the T-type thermocouples that were located in the mid-height of the cell. The characteristics of the T-type thermocouples offer that the accuracy of the temperature measurement as $\pm 1{ }^{\circ} \mathrm{C}$. 


\section{Model parameter analysis}

The electrochemical-thermal model requires significant number of geometrical, electrochemical, and thermal design and operating parameters as inputs. These parameters are presented and discussed in the following parts.

\subsection{Geometrical parameters}

In this study, a cylindrical Li-ion cell has been used that consists of a graphite anode, a separator, $\mathrm{Al}$ and $\mathrm{Cu}$ current collectors, and NCA $\left.(\mathrm{LiNiCoAlO})_{2}\right)$ cathode. A cylindrical $\mathrm{Li}$-ion cell consists of multiple layers around a mandrel as presented in Fig. 3 .

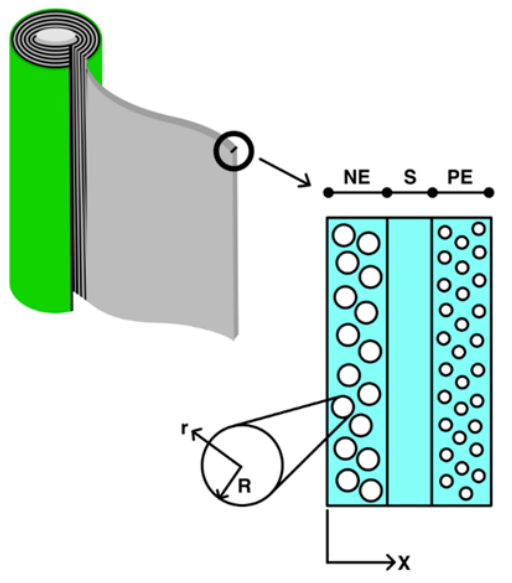

Fig. 3. Spiral structure of a Li-ion cell.

An extensive literature survey was conducted on the geometrical properties of a Li-ion cell. These properties are presented in Table 2. Note that MIV represents the model input value.

Table 2. Geometrical parameters of NCA and some other frequently used $\mathrm{Li}$-ion cells

\begin{tabular}{|c|c|c|}
\hline Symbol & Value & MIV \\
\hline $\mathrm{L}_{\mathrm{sep}}$ & $\begin{array}{c}10[23], 15[24], 13[25], 25 \\
{[26], 11.5[27] .}\end{array}$ & $13 \mu \mathrm{m}$ \\
\hline $\mathrm{L}_{\text {necc }}$ & $\begin{array}{c}10[23, \mathbf{2 4}, \mathbf{2 8}], 7.5[27,29], \\
18[30] .\end{array}$ & $10 \mu \mathrm{m}$ \\
\hline $\mathrm{L}_{\text {pecc }}$ & $\begin{array}{c}15[\mathbf{2 3}, \mathbf{2 8}], 14-16[\mathbf{2 4}], 30 \\
{[\mathbf{3 0}] .}\end{array}$ & $15 \mu \mathrm{m}$ \\
\hline $\mathrm{L}_{\mathrm{ne}}$ & $\begin{array}{c}110[\mathbf{2 3}], 190[\mathbf{2 4}], 205[\mathbf{2 5}] \\
88[\mathbf{2 6}], 61[\mathbf{2 7}], 42.6[\mathbf{2 8}], 35 \\
{[\mathbf{3 0}], 73.5[\mathbf{3 1}], 243[\mathbf{3 2}] .}\end{array}$ & $205 \mu \mathrm{m}$ \\
\hline $\mathrm{L}_{\mathrm{pe}}$ & $\begin{array}{c}125[\mathbf{2 3}], 165[\mathbf{2 4}], 158[\mathbf{2 5}], \\
80[\mathbf{2 6}], 55.4[\mathbf{2 7}], 32.8[\mathbf{2 8}], 35 \\
{[\mathbf{3 0}], 70[\mathbf{3 1}], 50[\mathbf{3 3}] .}\end{array}$ & $165 \mu \mathrm{m}$ \\
\hline$r_{\text {ne }}$ & $\begin{array}{c}2[\mathbf{2 6}], 11[\mathbf{2 9}, \mathbf{3 5}], 12.5[\mathbf{3 1} \\
\mathbf{3 4}], 18[\mathbf{3 2}]\end{array}$ & $11 \mu \mathrm{m}$ \\
\hline$r_{\text {pe }}$ & $\begin{array}{c}2[\mathbf{2 6}], 4[\mathbf{2 7}], 0.25[\mathbf{3 0}, \mathbf{3 6}], \\
8.5[\mathbf{3 1}], 2.5[\mathbf{3 3}, \mathbf{3 4}] .\end{array}$ & $2.5 \mu \mathrm{m}$ \\
\hline $\mathrm{r}_{\text {mandrel }}$ & $0.2[24], 2[37]$. & $2 \mathrm{~mm}$ \\
\hline $\mathrm{H}_{\text {cell }}$ & 65 & $65 \mathrm{~mm}$ \\
\hline $\mathrm{r}_{\text {cell }}$ & 9 & $9 \mathrm{~mm}$ \\
\hline $\mathrm{L}_{\text {shell }}$ & $\begin{array}{c}0.24 \text { [23], } 0.205 \text { [24], } 0.4 \\
\text { [38]. }\end{array}$ & $0.4 \mathrm{~mm}$ \\
\hline
\end{tabular}

$[\mathbf{2 6}, \mathbf{2 7}, \mathbf{3 1}] \mathrm{LiCoO}_{2}$ is used as positive electrode.

[28] Mg-NCA is used as positive electrode.

[36] Prismatic cell is used.
The separator thickness varies from 10 to $15 \mu \mathrm{m}$ in the references that involve NCA electrodes [23-25]. Moreover, positive and negative current collectors also have a considerably narrow range, from 15 to $30 \mu \mathrm{m}$, and 7.5 to $18 \mu \mathrm{m}$, respectively.

On the other hand, the electrode lengths found in the literature are rather variable, and need to be carefully selected for the model as they have significant impacts on the electrochemical modeling results. It changes from 35 to $243 \mu \mathrm{m}$ for negative electrode, and 35 to $165 \mu \mathrm{m}$ for positive electrode [23-28, 30-33].

The mandrel is located at the center of the cell. The material of the mandrel differs in two NCA battery applications, such as nylon and nickel foil with 2 and 0.2 $\mathrm{mm}$ radius, respectively [24, 37]. The effect of the mandrel will be discussed further.

The circles in Figures 1 and 2 display the active particles in the electrodes. Typically, these particles are not uniformly distributed and not in the shape of an exact sphere. However, in this model, we assume that particles are perfect spheres with an average radius. These values range from 2 to $18 \mu \mathrm{m}$ and 0.25 to $8.5 \mu \mathrm{m}$ for negative and positive electrodes, respectively from the literature [26, 27, 29-36].

The shell of a Li-ion cell consists of two parts such as PVC, and a metal can. Since these parts are small compared to others, most of the studies use the average properties of the shell and consider these two parts as one piece. The average shell thickness value was found as $0.204,0.25$, and $0.4 \mathrm{~mm}$ from the literature for various NCA cells, respectively [23, 24, 38]. On the other hand, the effect of the shell length is expected as almost negligible.

\subsection{Electrochemical parameters}

The electrical and chemical parameters have a significant role in 1-D electrochemical model behavior as they influence the voltage prediction of the cell during charge or discharge. Therefore, the related studies that mostly examine the NCA electrodes from the literature were investigated and various parameters were defined as presented in Table 3 .

Table 3. Electrical and chemical parameters of NCA and some other frequently used $\mathrm{Li}$-ion cells.

\begin{tabular}{|c|c|c|}
\hline Par. & Value & MIV \\
\hline$\varepsilon_{\mathrm{s}, \mathrm{ne}}$ & $0.58[27], 0.62[30,36]$. & 0.62 \\
\hline$\varepsilon_{\mathrm{s}, \mathrm{pe}}$ & $0.5[27], 0.482[30,36]$. & 0.482 \\
\hline$\varepsilon_{\mathrm{l}, \mathrm{ne}}$ & $\begin{array}{c}0.485[\mathbf{2 6}], 0.332[27], 0.4382 \\
{[31], 0.31[36] .}\end{array}$ & 0.31 \\
\hline$\varepsilon_{\mathrm{l}, \mathrm{pe}}$ & $\begin{array}{c}0.385[\mathbf{2 6}], 0.330[\mathbf{2 7}], 0.29 \\
{[\mathbf{3 0}, \mathbf{3 6}], 0.3[\mathbf{3 1}], 0.4[\mathbf{3 3}]}\end{array}$ & 0.29 \\
\hline$\varepsilon_{1, \mathrm{~s}}$ & $\begin{array}{c}0.724[\mathbf{2 6}], 0.5[27], 0.45 \\
{[31], 0.4[36] .}\end{array}$ & 0.42 \\
\hline $\mathrm{k}_{\mathrm{a}}$ & $\begin{array}{c}5.037 \mathrm{e}-11[26], 1.764 \mathrm{e}-11 \\
{[31], 2.334 \mathrm{e}-11[34]}\end{array}$ & $\begin{array}{c}1.764 \mathrm{e}-11 \\
\mathrm{~m}^{2.5} /\left(\mathrm{mol}^{0.5} \mathrm{~s}\right.\end{array}$ \\
\hline $\mathrm{k}_{\mathrm{c}}$ & $\begin{array}{c}2.334 \mathrm{e}-11[\mathbf{2 6}], 6.6667 \mathrm{e}-11 \\
{[31], 1 \mathrm{e}-10[\mathbf{3 3}, \mathbf{3 4}]}\end{array}$ & $\begin{array}{c}1 \mathrm{e}-10 \\
\mathrm{~m}^{2.5} /\left(\mathrm{mol}^{0.5} \mathrm{~s}\right. \\
\end{array}$ \\
\hline $\mathrm{p}_{\text {sep }}$ & $\begin{array}{c}{[26], 1.5[27], 2.3[31], 3} \\
{[34] .}\end{array}$ & ( \\
\hline $\mathrm{p}_{\mathrm{pe}}$ & $\begin{array}{c}1.5[\mathbf{2 7}, \mathbf{3 1}], 1.928[30], 2.89 \\
{[33] .}\end{array}$ & 2.89 \\
\hline
\end{tabular}




\begin{tabular}{|c|c|c|}
\hline$p_{\text {ne }}$ & $4.1[31], 3.3$ [27]. & 1.5 \\
\hline$\sigma_{\mathrm{s}, \mathrm{ne}}$ & $100[27, \mathbf{2 9}, \mathbf{3 1}, \mathbf{3 2}, \mathbf{3 5}]$. & $100 \mathrm{~S} / \mathrm{m}$ \\
\hline$\sigma_{\mathrm{s}, \mathrm{pe}}$ & $\begin{array}{c}91[\mathbf{3 0}, \mathbf{3 6}, \mathbf{3 7}], 10[\mathbf{2 7}, \mathbf{3 1}, \\
\mathbf{3 3}] .\end{array}$ & $91 \mathrm{~S} / \mathrm{m}$ \\
\hline$D_{s, n e}$ & $\begin{array}{c}3.9 \mathrm{e}-14[\mathbf{2 6}, \mathbf{3 4}], 5.5 \mathrm{e}-14 \text { [27], } \\
9 \mathrm{e}-14[\mathbf{2 9}, \mathbf{3 5}, \mathbf{3 9}], 3.17 \mathrm{e}-14 \\
{[\mathbf{3 0}], \text { Eqn. } 33 \text { [31], 5e-13 [32]. }}\end{array}$ & Eqn. $33 \mathrm{~m}^{2} / \mathrm{s}$ \\
\hline$D_{s, p e}$ & $\begin{array}{c}1 \mathrm{e}-14 \text { [26], 1e-11 [27, 31], } \\
(1.11-1.63) \mathrm{e}-15 \text { [30, 36], Eqn. } \\
34[\mathbf{3 3}, \mathbf{3 4}],(2-3) \mathrm{e}-14 \text { [40]. }\end{array}$ & Eqn. $34 \mathrm{~m}^{2} / \mathrm{s}$ \\
\hline$c_{l, \text { init }}$ & $\begin{array}{c}1000[\mathbf{2 6}, \mathbf{3 1}], 1200[\mathbf{2 7}, \mathbf{3 0} \\
\mathbf{3 7}] .\end{array}$ & $1200 \mathrm{~mol} / \mathrm{m}^{3}$ \\
\hline $\mathrm{E}_{\mathrm{eq}, \mathrm{ne}}$ & $\begin{array}{c}\text { Eqn. } 37 \text { [26], Eqn. } 36[34], \\
\text { Eqn. } 35[39,41] .\end{array}$ & Eqn. $35 \mathrm{~V}$ \\
\hline$E_{\text {eq,pe }}$ & Eqn. 39 [26], Eqn. 38 [34], & Eqn. $38 \mathrm{~V}$ \\
\hline $\mathrm{c}_{\max , \mathrm{p}}$ & $\begin{array}{c}51554[\mathbf{2 6}], 49943[\mathbf{3 1}], \\
49459.2 \text { [34]. } \\
\end{array}$ & $48000 \mathrm{~mol} / \mathrm{m}^{3}$ \\
\hline$c_{\max , n}$ & $\begin{array}{c}30555[\mathbf{2 6}], 31858[\mathbf{3 1}], \\
26389[\mathbf{3 4}] .\end{array}$ & $31507 \mathrm{~mol} / \mathrm{m}^{3}$ \\
\hline
\end{tabular}

Eqn. $33=1.4523 \mathrm{e}-13 * \exp \left(68025.7 / 8.314 *\left(1 / \mathrm{T}_{\text {ref }}-1 / \mathrm{T} 2\right)\right.$

Eqn. $34=3 \mathrm{e}-15 *\left(\left(1+\tanh \left(-20\left(\mathrm{SOC}_{\mathrm{NCA}}-0.73\right)\right)+0.02\right.\right.$

It is challenging to determine the solid and liquid phase volume fractions by experimental methods. However, the previous studies could be useful, which were presented in Table 2. The investigated volume fractions vary in a very narrow range considering the NCA batteries $[30,36]$ and the other type of batteries $[26,27,31]$.

The reaction rate coefficients of an NCA battery were found as 1e-10 for the positive electrode, and $2.334 \mathrm{e}-11$ for negative electrode [33, 34]. Some parameters are difficult to achieve since the literature suffers from the lack of NCA battery modeling applications. Therefore, it could be useful to have information about the same parameters of the other type of batteries, such as $\mathrm{LiCoO}_{2}$, as they are provided in the table above [26, 31].

The diffusion coefficients of negative and positive electrodes are mostly taken as constant in the battery model applications [26, 27, 29-32, 34-36, 40]. In one application, the negative electrode diffusion coefficient is considered a function of temperature [31]. Besides, in a few studies, it was found that the diffusion coefficient of positive electrode varies with $\mathrm{SOC}_{\mathrm{NCA}}[33,34]$. On the other hand, the effective diffusion coefficients can be calculated by using the Bruggeman coefficients [26, 27, 30, 31, 33, 34].

The electrical conductivity of the graphite electrode is $100 \mathrm{~S} / \mathrm{m}$ in each presented research $[27,29,31,32$, 35]. However, there are two dissimilar electrical conductivities of the NCA electrode as 10 [27, 31, 33], and $91 \mathrm{~S} / \mathrm{m}[30,36,37]$.

The equilibrium potentials of the electrodes were defined from studies [34], [39] and [41]. Furthermore, the similar equilibrium voltage plots that were used in other battery model applications can be found from studies [26] and [34].

\subsection{Thermal parameters}

Thermal parameters of the mandrel, active material, and shell were obtained from the literature and presented in Table 4.

Table 4. Thermal parameters of NCA and some other frequently used Li-ion cells.

\begin{tabular}{|c|c|c|}
\hline Symbol & Value & MIV \\
\hline$c_{p, \text { mandrel }}$ & $1700[37,42], 460[43]$. & $460 \mathrm{~kJ} / \mathrm{kgK}$ \\
\hline$c_{p, p e}$ & $1000[\mathbf{3 6}], 1249$ [28]. & - \\
\hline$c_{p, n e}$ & $\begin{array}{c}1000 \text { [36], } 1437.4 \text { [44], } \\
881.7 \text { [28]. }\end{array}$ & - \\
\hline$c_{p, p e c c}$ & $\begin{array}{c}897 \text { [36], } 903 \text { [45], } 896.9 \\
\text { [28]. }\end{array}$ & - \\
\hline$c_{p, \text { necc }}$ & $\begin{array}{c}384[36], 385[45], 384.6 \\
{[28] .}\end{array}$ & - \\
\hline$c_{p, s e p}$ & $\begin{array}{c}1046[36], 1978.16[44], \\
1859.9[28] . \\
\end{array}$ & - \\
\hline$c_{p, c e l l}$ & $\begin{array}{c}868.12 \text { [46], } 700 \text { [47], } 830 \\
\text { [48]. }\end{array}$ & $750 \mathrm{~kJ} / \mathrm{kgK}$ \\
\hline$c_{p, \text { shell }}$ & $875[\mathbf{3 8}]$. & $875 \mathrm{~kJ} / \mathrm{kgK}$ \\
\hline$c_{p, p e c c}$ & $1150[37,42], 8890[49]$. & $8890 \mathrm{~kJ} / \mathrm{kgK}$ \\
\hline$\rho_{\text {cell }}$ & 2782 [Measured]. & $2782 \mathrm{~kg} / \mathrm{m}^{3}$ \\
\hline$\rho_{\text {shell }}$ & 2059 [38]. & $2059 \mathrm{~kg} / \mathrm{m}^{3}$ \\
\hline$\lambda_{\text {mandrel }}$ & $0.26[37,42], 70[49]$. & $70 \mathrm{~W} / \mathrm{mK}$ \\
\hline$\lambda_{\mathrm{pe}}$ & $3.4[\mathbf{3 6}], 1.58[\mathbf{4 4}], 5[\mathbf{5 0}]$. & $5 \mathrm{~W} / \mathrm{mK}$ \\
\hline$\lambda_{\text {ne }}$ & 1 [39], 1.04 [44], 5 [50]. & $1.04 \mathrm{~W} / \mathrm{mK}$ \\
\hline$\lambda_{\text {pecc }}$ & $\begin{array}{c}237[28, \mathbf{3 6}, \mathbf{3 9}, \mathbf{5 1}], 238 \\
{[4 \mathbf{4 4}, \mathbf{4 5}] .}\end{array}$ & $237 \mathrm{~W} / \mathrm{mK}$ \\
\hline$\lambda_{\text {necc }}$ & $\begin{array}{c}401[\mathbf{2 8}, \mathbf{3 6}, \mathbf{3 9}, \mathbf{5 1}], 398 \\
{[\mathbf{4 4 , \mathbf { 4 5 } ]} .} \\
\end{array}$ & $398 \mathrm{~W} / \mathrm{mK}$ \\
\hline$\lambda_{\text {sep }}$ & $\begin{array}{c}0.16[31], 0.15[36], 0.3344 \\
{[44] .}\end{array}$ & $0.3344 \mathrm{~W} / \mathrm{mK}$ \\
\hline$\lambda_{\mathrm{r}}$ & Eqn. 40. & $1.49 \mathrm{~W} / \mathrm{mK}$ \\
\hline$\lambda_{\mathrm{a}}$ & Eqn. 41. & $20.92 \mathrm{~W} / \mathrm{mK}$ \\
\hline$\lambda_{\text {shell }}$ & $13.57[\mathbf{2 3}, \mathbf{5 2}], 0.638[\mathbf{3 8}]$. & $0.638 \mathrm{~W} / \mathrm{mK}$ \\
\hline$\varepsilon$ & 0.6 & 0.6 \\
\hline
\end{tabular}

Note that the radial and angular thermal conductivity of the cell can be obtained using the Eqns. (40-42).

$$
\begin{gathered}
\lambda_{\text {rd }}=\frac{L_{\text {bat }}}{\frac{L_{\text {pe }}}{\lambda_{\text {pe }}}+\frac{L_{\text {neg }}}{\lambda_{\text {neg }}}+\frac{L_{\text {pecc }}}{\lambda_{\text {pecc }}}+\frac{L_{\text {necc }}}{\lambda_{\text {necc }}}+\frac{L_{\text {sep }}}{\lambda_{\text {sep }}}} \\
\lambda_{\text {ang }}=\frac{+L_{\text {necc }} \lambda_{\text {necc }}+L_{\text {sep }}+\lambda_{\text {sep }}}{L_{\text {bat }}} L_{\text {ne }}+L_{\text {pecc }} \lambda_{\text {pecc }}
\end{gathered}
$$

where $\mathrm{L}_{\text {bat }}$ can be evaluated as,

$$
\mathrm{L}_{\text {bat }}=\mathrm{L}_{\text {ne }}+\mathrm{L}_{\text {necc }}+\mathrm{L}_{\text {sep }}+\mathrm{L}_{\text {pe }}+\mathrm{L}_{\text {pecc }}
$$

It is seen that the thermal parameters of the Li-ion cell are found to be consistent compared to the geometrical, electrical and chemical parameters. Only a few discrepancies have been encountered in the literature. It was found that the mandrel material of an NCA battery is used differently in some applications 
$[37,42,43,49]$. Table 5 compares the thermal properties of the mandrel.

Table 5. Thermal parameters of the nylon and nickel foil mandrel.

\begin{tabular}{|c|c|c|}
\hline Property & $\begin{array}{c}\text { Nylon [37, } \\
\mathbf{4 2}]\end{array}$ & $\begin{array}{c}\text { Nickel Foil } \\
{[43,49]}\end{array}$ \\
\hline Heat Capacity & $\begin{array}{c}1700 \\
\mathrm{~J} / \mathrm{kgK}\end{array}$ & $460 \mathrm{~J} / \mathrm{kgK}$ \\
\hline Density & $\begin{array}{c}1150 \\
\mathrm{~kg} / \mathrm{m}^{3}\end{array}$ & $8890 \mathrm{~kg} / \mathrm{m}^{3}$ \\
\hline Thermal conductivity & $\begin{array}{c}0.26 \\
\mathrm{~W} /(\mathrm{mK})\end{array}$ & $70 \mathrm{~W} /(\mathrm{mK})$ \\
\hline Relative permittivity & 4 & 110 \\
\hline $\begin{array}{c}\text { Coefficient of thermal } \\
\text { expansion }\end{array}$ & $\begin{array}{c}280 \mathrm{e}-6 \\
(1 / \mathrm{K})\end{array}$ & $13.3 \mathrm{e}-6(1 / \mathrm{K})$ \\
\hline Young's modulus & $2 \mathrm{GPa}$ & $207 \mathrm{GPa}$ \\
\hline Poisson's ratio & 0.4 & 0.31 \\
\hline
\end{tabular}

After all parameters were analyzed, the electrochemical-thermal coupled model is ready to run with the indicated model input values (MIV). The results are presented in the next section.

\section{Results}

An NCR18650b cylindrical Li-ion cell was fully charged as an initial condition and the thermal and electrical behavior of the cell was observed during $0.5 \mathrm{C}$, $1 \mathrm{C}$, and $1.5 \mathrm{C}$ rate discharging processes at $20^{\circ} \mathrm{C}$ temperature.

The voltage predictions were presented with the experimental results in Fig. 4. The coupled model is able to predict the voltage variation of the cell within a narrow margin of error for each discharging process.

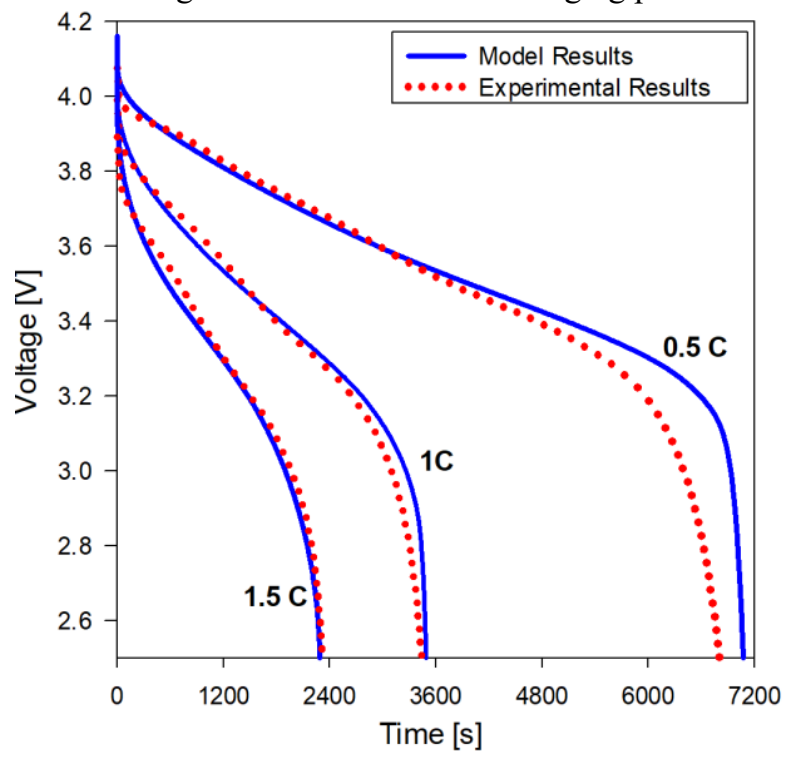

Fig. 4. Model and experimental voltage variation of the Liion cell during discharging processes.

The maximum voltage errors were obtained as 0.10 $\mathrm{V}, 0.30 \mathrm{~V}$, and $0.62 \mathrm{~V}$ during the $1.5 \mathrm{C}, 1 \mathrm{C}$, and $0.5 \mathrm{C}$ rate discharging processes, respectively. The model plots mostly follow the experimental data but the characteristics of the Li-ion cell cause a sharp voltage decrease towards the end of the discharging processes so that the differences arise. However, if we evaluate the entire process, the model results are reasonable since the maximum RMS (Root mean square) error is found as $0.11 \mathrm{~V}$ for the $0.5 \mathrm{C}$ rate discharging.

The temperature differences between the ambient and the surface of the cell were also measured during the 0.5-1-1.5 $\mathrm{C}$ rate discharging processes. The model results were compared with the experimental results, as presented in Fig. 5.

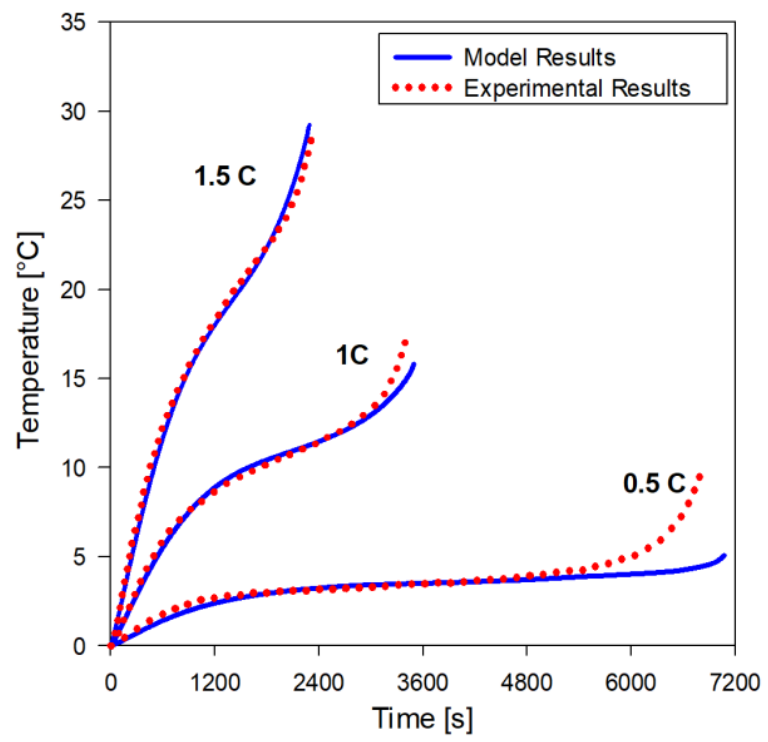

Fig. 5. Temperature change within the cell during various discharging processes.

The model results follow the same trend for each discharging process. The RMS errors were obtained as $0.56{ }^{\circ} \mathrm{C}, 0.53{ }^{\circ} \mathrm{C}$, and $0.96{ }^{\circ} \mathrm{C}$ for the $1.5 \mathrm{C}, 1 \mathrm{C}$, and 0.5 $\mathrm{C}$ rate discharging processes, respectively. On the other hand, the accuracy of the voltage predictions affects the thermal behavior of the model regarding the irreversible heat generation within the cell. Small voltage deviation towards the end of the discharging process causes a relatively large temperature deviation for the last few seconds of the $0.5 \mathrm{C}$ rate simulation.

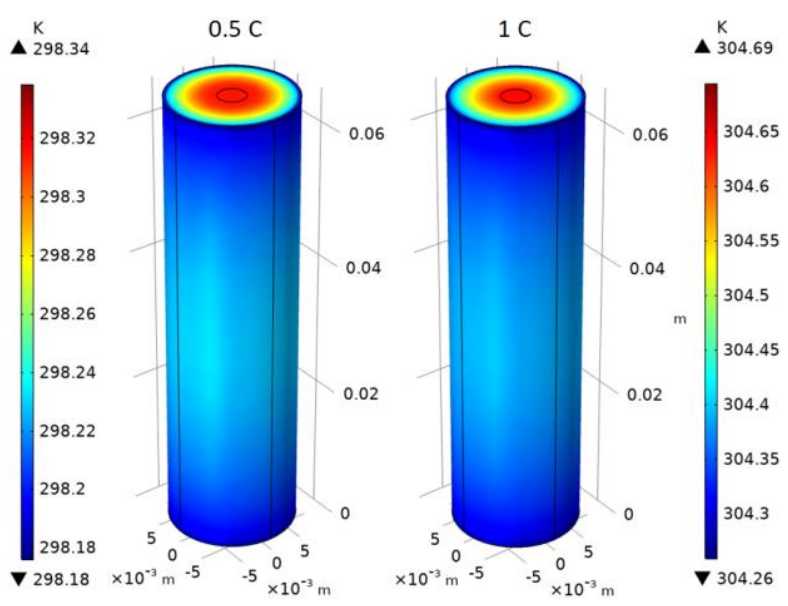

Fig. 6. 3-D Temperature distributions within the cell after it is completely discharged with 0.5 and $1 \mathrm{C}$ rates.

Fig. 6 compares the temperature distribution within the cell after a $0.5 \mathrm{C}$ and $1 \mathrm{C}$ rate discharging processes. The temperature differences within the cell were obtained as $0.16{ }^{\circ} \mathrm{C}$ and $0.43{ }^{\circ} \mathrm{C}$, after the $0.5 \mathrm{C}$ and $1 \mathrm{C}$ 
rate discharging processes, respectively. Therefore, the 3-D thermal model results deduce that the lumped modeling method could be applicable for the cases that apply relatively low discharge currents to the cell.

The results for the $1.5 \mathrm{C}$ rate discharging processes are used to investigate the effects of the mandrel material. The model results that use nickel foil as a mandrel material are presented in Fig. 7. The multi-slice geometry of the cell is also displayed in the figure so that the temperature variation within the cell can be observed in detail.

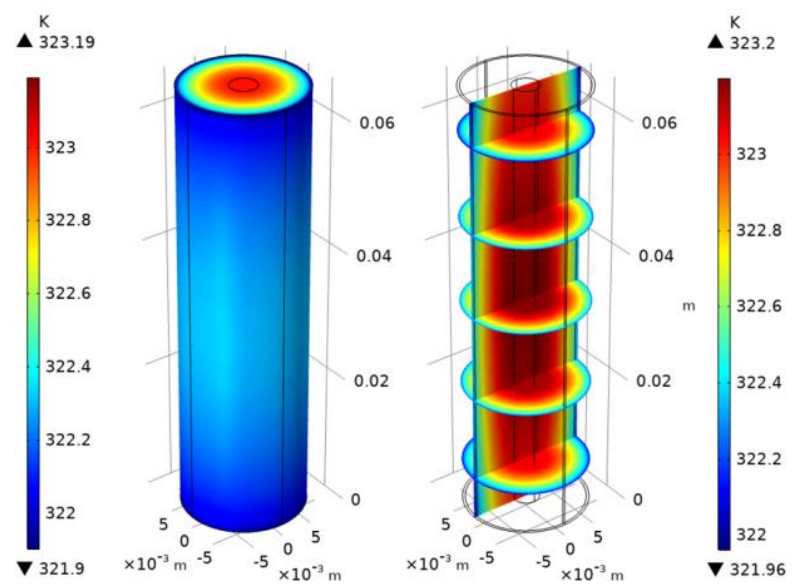

Fig. 7 Temperature distributions for the cylindrical and multislice cell geometries after a $1.5 \mathrm{C}$ rate discharging of a Nickel mandrel cell.

Besides, nylon is used as a mandrel material in the coupled model in order to investigate the effects of the mandrel on the thermal behavior of the Li-ion cell. The results after a $1.5 \mathrm{C}$ rate discharging process were presented in Fig. 8 for the cylindrical and multi-slice geometry of the cell.

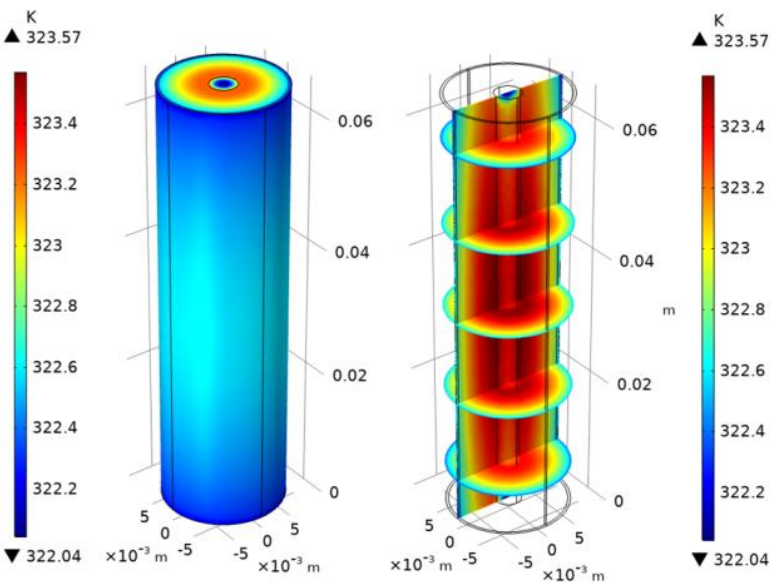

Fig. 8. Temperature distributions for the cylindrical and multislice cell geometries after a $1.5 \mathrm{C}$ rate discharging of a Nylon mandrel cell.

Figure 7 and 8 show that changing the material of the mandrel alters the temperature variation within the cell. First, the maximum temperature within the cell can now be observed in the active material around the mandrel. Furthermore, as can be seen in Fig. 8, there is a small cold region at the top of the mandrel. Besides, the maximum temperature of the cell is increased by 0.37 ${ }^{\circ} \mathrm{C}$ using nylon as a mandrel. Finally, a comparable cell average surface temperature was obtained, $322.7 \mathrm{~K}$ for the nylon, and $322.41 \mathrm{~K}$ for the nickel foil mandrel cell.

\section{Conclusions}

Following conclusions can be obtained from the study:

- Careful and judicial selection of geometric, electrochemical and thermal parameters is absolutely necessary for successful modeling Li-ion cells.

- For low discharge rates, the temperature distribution inside the cell is almost uniform. The temperature differences within the cell were obtained as $0.16{ }^{\circ} \mathrm{C}$ and $0.43{ }^{\circ} \mathrm{C}$, after the $0.5 \mathrm{C}$ and $1 \mathrm{C}$ rate discharging processes, respectively.

- Mandrel material affects the temperature distribution within the cell. The maximum temperature difference within the cell was found to be $1.29{ }^{\circ} \mathrm{C}$ and $1.5{ }^{\circ} \mathrm{C}$ after a 1.5 -C rate discharging process for the nickel and the nylon mandrel cell, respectively. Nylon material causes a small cold temperature region at the surface of the mandrel. Besides, the low conductive nylon mandrel also changes the maximum temperature region to the outside of the mandrel.

- $\quad$ The predicted temperature and voltage profiles follow the same trend as the experimental data and are consistent at each discharging condition. The maximum calculated root mean square errors were obtained as $0.11 \mathrm{~V}$ for the voltage predictions, and $0.96{ }^{\circ} \mathrm{C}$ for the temperature predictions. Therefore, the developed model can predict the electrochemical and thermal performances of a Li-ion cell successfully.

\section{References}

1. Y. Li, F. Qi, H. Guo, Z. Guo, M. Li, W. Wu, Case Stud. Therm. Eng., 13, 100387, (2019).

2. M. Hou, Y. Hu, J. Zhang, H. Cao, Z. Wang, Electrochim. Acta, 347, 136280, (2020).

3. F. Bahiraei, M. Ghalkhani, A. Fartaj, G-A Nazri, Appl. Therm. Eng., 125, 904, (2017).

4. K. Darcovich, D. D. MacNeil, S. Recoskie, B. Kenney, Appl. Therm. Eng., 133, 566, (2018).

5. Z. An, L. Jia, L. Wei, C. Dang, Q. Peng, Appl. Therm. Eng., 137, 792, (2018).

6. G. Jiang, L. Zhuang, Q. Hu, Z. Liu, J. Huang, Appl. Therm. Eng., 171, 115080, (2020).

7. Y. Huang, H. Lai, Appl. Therm. Eng., 157, 113744, (2019).

8. M. Xu, Z. Zhang, X. Wang, L. Jia, L. Yang, Energy, 80, 303, (2015).

9. D-C Lee, C-W Kim, J. Power Sources, 475, 228678, (2020) 
10. M. Mastali, E. Foreman, A. Modjtahedi, E. Samadani, A. Amirfazli, S. Farhad, R. A. Fraser, M. Fowler, Int. J. Therm. Sci., 129, 218, (2018).

11. P. Nie, S-W Zhang, A. Ran, C. Yang, S. Chen, Z. Li, X. Zhang, W. Deng, T. Liu, F. Kang, G. Wei, Appl. Therm. Eng., 184, 116258, (2021).

12. D. H. Jeon, Curr. Appl. Phys., 14, 196, (2014).

13. X. Han, Y. Huang, H. Lai, Appl. Therm. Eng., 147, 908, (2019).

14. J. Chiew, C. S. Chin, W. D. Toh, Z. Gao, J. Jia, C. Zhang, Appl. Therm. Eng., 147, 450, (2019).

15. M. Xu, Z. Zhang, X. Wang, L. Jia, L. Yang, J. Power Sources, 256, 233, (2014).

16. XR Kong, B. Wetton, B. Gopaluni, IFACPapersOnline, 52 (1), 946, (2019).

17. L. Cai, R. E. White, J. Power Sources, 196, 5985, (2011).

18. R. Bubbico, V. Greco, C. Menale, Safety Science, 108, 72, (2018).

19. H. Liu, Z. Wei, W. He, J. Zhao, Energy Convers. Manag., 150, 304, (2017).

20. M. Doyle, T.F. Fuller, J. Newman, J. Electrochem. Soc. 140 (6), 1526, (1993).

21. J. Newman, W. Tiedemann, AIChE J., 21 (1), 25, (1975).

22. D. Bernardi, E. Pawlikowski, J. Newman, J. Electrochem. Soc., 132 (1), 5, (1985).

23. Y. Xie, W. Li, Y. Yang, F. Feng, Int. J. Energy Res., 42, 4481, (2018).

24. M. Hagen, D. Hanselmann, K. Ahbrecht, R. Maça, D. Gerber, J. Tübke, Adv. Energy Mater., 5, 1401986, (2015).

25. D. Krsmanovic, Development of a property forecast tool for flexible compositions of Li-ion batteries, including raw material availability and price forming, Master Thesis, Uppsala University, (2019).

26. V. R. Subramanian, V. Boovaragavan, V. Ramadesigan, M. Arabandi, J. Electrochem. Soc., 156 (4), A260, (2009).

27. M. Doyle, Y. Fuentes, J. Electrochem. Soc., 150 (6), A706, (2003).

28. H. Kondo, N. Baba, Y. Makimura, Y. Itou, T. Kobayashi, J. Power Sources, 448, 227464, (2020).

29. J. Christensen, V. Srinivasan, John Newman, J. Electrochem. Soc., 153 (3), A560, (2006).

30. S. Brown, N. Mellgren, M. Vynnycky, G. Lindbergha, J. Electrochem. Soc., 155 (4), A320, (2008).

31. K. Kumaresan, G. Sikha, R. E. White, J. Electrochem. Soc., 155 (2), A164, (2008).

32. T. F. Fuller, M. Doyle, J. Newman, J. Electrochem. Soc., 141 (1), 1, (1994).

33. P. Albertus, J. Christensen, J. Newman, J. Electrochem. Soc., 156 (7, A606, (2009).

34. Y. Dai, L. Cai, R. E. White, J. Power Sources 247, 365, (2014).
35. S. G. Stewart, V. Srinivasan, J. Newman, J. Electrochem. Soc., 155 (9), A664, (2008).

36. T. G. Zavalis, M. Behm, G. Lindbergh, J. Electrochem. Soc.”, 159 (6), A848, (2012).

37. COMSOL Multiphysics Reference Manual, version 5.4", COMSOL, Inc, www.comsol.com.

38. E. Gümüşsu, Ö. Ekici, M. Köksal, Appl. Therm. Eng., 120, 484, (2017).

39. R. Gerver, J. Meyers, J. Electrochem. Soc., 158 (7), A835, (2011).

40. R. Amin, D. B. Ravnsbæk, Y-M Chianga, J. Electrochem. Soc., 162 (7), A1163, (2015).

41. M. W. Verbrugge, Brian J. Koch, J. Electrochem. Soc., 150 (3), A374, (2003).

42. N. Yang, X. Zhang, G. Li, D. Hua, Appl. Therm. Eng., 80, 55, (2015).

43. MatWeb Material Property Data, accessed August 2021,<http://www.matweb.com/search/DataSheet. aspx?MatGUID=e6eb83327e534850a062dbca3bc $758 \mathrm{dc}>$

44. S. C. Chen, C. C. Wan, Y. Y. Wang, J. Power Sources, 140 (1), 111, (2005).

45. G. F. Hewitt, G. L. Shires, T.R. Bott, Process Heat Transfer, CRC Press, London, 1995.

46. Y-S Duh, M-T Tsai, C-S Kao, J. Therm. Anal. Calorim., 127, 983, (2017).

47. J. K. Carroll, M. Alzorgan, C. Page, A. R. Mayyas, Active Battery Thermal Management within Electric and Plug-In Hybrid Electric Vehicles, SAE Technical Paper, 2016-01-2221, (2016).

48. M. Taffal, Electro-Thermal Modelling of LithiumIon Battery, Master Thesis, Polytechnic University of Turin, (2019).

49. Nickel-Alloys.net, accessed August 2021, $<$ https://www.nickelalloys.net/commercially_pure_nickel.html>

50. D. R. Baker, M. W. Verbrugge, J Electrochem. Soc., 146 (7), 2413, (1999).

51. CRC Handbook of Chemistry and Physics, CRC Press, Cleveland, Ohio, (1977).

52. T. Wang, K. J. Tseng, J. Zhao, Z. Wei, Appl. Energy, 134, 229, (2014). 